\title{
ATAT1 Gene
}

National Cancer Institute

\section{Source}

National Cancer Institute. ATAT1 Gene. NCI Thesaurus. Code C94840.

This gene may be involved in neuronal development. 